\title{
FACTORS OF A HEALTHY WAY OF LIFE OF UKRAINIAN SCHOOLCHILDREN IN INSTITUTION OF GENERAL SECONDARY EDUCATION
}

\author{
Yassin Mohamed Ali Abdel \\ Assistant Professor at the Department of Foreign Philology, Institute of Philology \\ and Journalism, V. I. Vernadsky Taurida National University, Ukraine \\ e-mail: 21111970y@gmail.com,orcid.org/0000-0002-0891-2069
}

\section{Summary}

The article analyzes the factors influencing the formation of a healthy lifestyle of schoolchildren in institution of general secondary education ZZSO. The role of the health of the conservation environment is noted. Regulatory documents and research on the culture of health and psychological health of the individual are analyzed. The state of the organization of the health of the conservation environment in ZZSO and the factors that negatively affect the psychological health of students in ZZSO: the shift of landmarks from moral family values to the material and social situation in society; uncontrolled use of media and Internet resources by students and adolescents; limited motor activity of students (hypodynamics); lack of systematic and purposeful work on the prevention of unhealthy habits (smoking, alcohol, drugs, gambling and Internet addiction and other deviations).

Solving the problem of maintaining the health of children and adolescents, teaching a healthy lifestyle, taking into account the factors of a healthy lifestyle of schoolchildren and pupils requires joint attention: teachers, doctors, parents, members of the public. A special place and responsibility for health activities is given to the domestic modern educational system, which should make the educational process healthy.

Keywords: health, healthy lifestyle, environment, pupils.

DOI: https://doi.org/10.23856/3856

\section{Introduction}

Tetiana Bakhteieva, the Head of the Committee of Verkhovna Rada of Ukraine (literally Supreme Council of Ukraine) on Public Health, Medical Assistance and Medical Insurance in the course of parliamentary hearings "Health 2020" noted that, based on data of the World Health Organization, a lifestyle is the most significant factor determining the health condition of a person [A person's health condition for 50\% depends on their lifestyle - WHO]. Thus, at the present time in the $21^{\text {st }}$ century, the primary goal of the state, the community, and educational institutions is to form a harmonious personality that is healthy physically and spiritually.

$\mathrm{Yu}$. Boichuk notes the existence of over 450 definitions of the concept of "health" (Boichuk, 2018). Health is the state of complete physical, mental, and social well-being. Health is a harmonious unity of biological and social qualities, predetermined by inborn and acquired biological and social factors (a disease violates this unity and harmony).

$A$ healthy lifestyle is "a condition of optimal body functioning" and usage of own life potential (Pidborskyi, 2016). Among the factors affecting the condition of health are the external environment, sanitary and hygienic living and studying conditions, etc.

Health preserving environment is the priority of the health-improving objective of the educational process in institutions of general secondary education (hereinafter referred to as 
IGSE) in the conditions of the New Ukrainian School. Therefore, the tasks of IGSE today include the following: formation of students' conscious attitude to life and health; development of healthy lifestyle skills in students; formation of health-preserving competence of school children. The health of children and youth is one of the components of national development in Ukraine. At the legislative level, this is provided for by the Laws of Ukraine "On Education," "On General Secondary Education," "On Extracurricular Education," "The Concept of the New Ukrainian School" and others. They provide for the formation of a healthy lifestyle and the provision of conditions for the physical and psycho-emotional development of the individual. The task of IGSE is to form a conscious attitude to the health of oneself and the health of other people as the highest social value, as well as to develop hygienic skills and principles of a healthy lifestyle, maintaining and strengthening the physical and mental health of students (pupils), etc.

\section{The main text}

We agree with the opinion of V. Kornatskyi that Ukrainians have health problems, that "the current condition of health and lifestyle of children and young people are a threat to the future of our country. Today, one in five children is born with a certain medical condition. Chronic diseases of the heart, spine, eye diseases, neuroses, obesity, etc. progress rapidly in the younger generation." (Kornatskyi, n.d.).

The formation of a healthy lifestyle in students and young people is one of the leading roles of the state. After all, the health of young people is one of the most important indicators of the country's development in general. One of the factors, signaling about the deterioration of health among students and young people, is the low level of motivation to preserve and maintain a good health condition, its rational formation and strengthening throughout life; therefore, life skills training is the necessary element of quality national education that will promote the appearance of competitive graduates in the employment and labor market. IGSE graduates in conditions of NUS implementation need to acquire psychosocial skills: think critically and creatively, adequately perceive themselves and the environment, make informed decisions, build constructive interpersonal relationships, work in a team, demonstrate leadership skills, interest and motivate others, solve problems and manage stress levels.

Health is the main wealth. A person who is not bothered by illnesses, who feels well, stays young and productive longer. The World Health Association (WHO) notes that health is the well-being of the body, mind, spirit, social ties, and the environment. Therefore, health care is one of the main tasks of every person, regardless of age, interests, wealth, and place of residence.

The global strategies of WHO, UNESCO, UNICEF promoting the health of children and adolescents are based on a holistic 8-component model of a child-friendly school environment: teaching students to maintain a healthy lifestyle; physical education lessons, extracurricular physical activity; school medical service; school meals and the availability of respective infrastructure; counseling, psychological and social aid; safe physical and socio-psychological environment; training of school staff on health and healthy living; involvement of parents and community.

\section{Research historiography}

A number of meaningful scientific researches has been devoted to the preservation and improvement of health of school children and young people, namely the researched by M. Bashmakov, Ya. Berehovyi, H. Spicenko, A. Tsymbalaru, V. Shypko, V. Kovalko, M. Malashenko. 
The improvement of health in health-promoting learning environment, the improvement of health in school children have been described in the works of Yu. Boichuk, M. Honcharenko, K. Huz, V. Ilchenko, A. Liashenko, P. Matviienko, V. Moliako, N. Denysenko, H. Nikiforova, N. Bibik, O. Savchenko, O. Bondarenko, V. Nesterenko, V. Sydorenko and others.

At the present time, education should shape the personality "on the basis of life skills" proposed by WHO (World Health Organization), UNICEF (United Nations Children's Fund), UNESCO (United Nations Educational, Scientific and Cultural Organization), World Bank at the World Education Forum (Dakar, Senegal, 2000). Life skills (as defined by the WHO) are the ability to adaptive and positive behavior, which allows you to effectively cope with the demands and problems of everyday life.

Table 1

Components and indicators of human health

\begin{tabular}{|c|c|}
\hline $\begin{array}{l}\text { Components of } \\
\text { human health }\end{array}$ & Indicators \\
\hline Physical health & $\begin{array}{l}\text { - a state of physical strength and well-being in which the body properly performs } \\
\text { its functions; when the indicators of the main systems are within the physiologi- } \\
\text { cal norm and change adequately during human interaction with the environment; } \\
\text { includes such factors as individual features of anatomical structure of a body, } \\
\text { physiological functions of an organism in various conditions of rest, movement, } \\
\text { environment, genetic heritage, level of physical development of organs and sys- } \\
\text { tems of an organism. }\end{array}$ \\
\hline $\begin{array}{l}\text { Psychological } \\
\text { health of human }\end{array}$ & $\begin{array}{l}\text { - psychological health characterizes the individual as a whole, is directly related } \\
\text { to the demonstration of the human spirit and allows us to highlight the actual } \\
\text { psychological aspect of the problem of mental health. According to I. Dubrovina, } \\
\text { the basis of psychological health is full-fledged mental development at all stages } \\
\text { of a child's growth. The field of mental health includes individual features of } \\
\text { mental processes and human characteristics, such as excitability, emotionality, } \\
\text { sensitivity }\end{array}$ \\
\hline $\begin{array}{l}\text { Emotional and } \\
\text { spiritual health }\end{array}$ & $\begin{array}{l}\text { - depend on the spiritual world of the individual, due to their relationship with } \\
\text { such components as education, science, religion, morality, ethics. This is a } \\
\text { person's consciousness, their mentality, vital self-identification, attitude to the } \\
\text { meaning of life, assessment of the implementation of their own abilities and } \\
\text { capabilities - all this determines the state of spiritual and emotional health of } \\
\text { the individual. This is the ability to manage their experiences, attitudes towards } \\
\text { themselves, friends and the needs of life, and so on. }\end{array}$ \\
\hline Social health & $\begin{array}{l}\text { - related to social and economic factors, family relationships, various social } \\
\text { structures (place of study/work, leisure, life, level of social protection, health, } \\
\text { safety, etc.). It is significantly influenced by risky behavior, social status, place of } \\
\text { residence and social environment; respect for the spiritual values of their family, } \\
\text { people, all humanity. }\end{array}$ \\
\hline $\begin{array}{l}\text { Intellectual } \\
\text { health }\end{array}$ & $\begin{array}{l}\text { - covers the norm of the structural and functional basis of intelligence demon- } \\
\text { strated in the normal solution of various problems of verbal-logical and logi- } \\
\text { cal-algorithmic interaction with the environment; }\end{array}$ \\
\hline
\end{tabular}

The new educational standards, which the New Ukrainian School is based on, take into account the "Recommendations of the European Parliament and the Council of Europe on the Formation of Key Competences in Lifelong Learning" (2006), and guide teachers to develop 
ten key competencies, namely, communication using official state language (and native language, if different); communication in foreign languages; mathematical literacy; competence in natural sciences and technologies; information and digital competence; ability to learn throughout life; social and civic competencies; entrepreneurship; general cultural literacy; environmental literacy and healthy living.

The purpose of the educational field "Health and Physical Culture" in the context of NUS is "the development of health conservation competence by students acquiring skills to maintain, strengthen, use health and care for it, readiness to act in emergencies."

Scientists argue that today the condition for improving and strengthening the health of students is to create a healthy environment: the optimal combination of methods, forms, means of teaching and education, taking into account the age peculiarities of students. In the $21^{\text {st }}$ century it is important to use innovative methods and teaching aids, to form the formation of key and subject competencies of students, to teach them to adhere to the motor activity. An important component of health promotion is also to provide an emotionally favorable atmosphere for learning and forming a health culture in students and their parents.

Thus, personal health is self-improvement and self-development, self-esteem and the freedom to be a personality. Health is a state of self-regulation of the body, the mutually coordinated action of all components of human health: spiritual, social, psychological, intellectual, emotional, physical and personal. They are equally important and should be considered in conjunction.

\section{Healthy life-style in the 21 st century}

A healthy lifestyle is an increase in productivity in all spheres of life, the formation of a value system (Erasov, 2000). It is the organization of personal activities aimed at strengthening and developing personal and public health. Our well-being and productivity are a balance of energy consumption and energy replenishment, training, work and physical activity, sports, etc. It is important to take care of the formation, preservation and strengthening of own (individual) and public health. For example, sleep has a special role. Healthy, proper sleep is the most effective way of optimal recovery and detoxification, given to us by nature. It is proved that without sleep, accumulating energy losses, a person gradually loses physical fitness. It reduces the body's protective functions, including immunity. Such person runs the risk of getting sick. In this case, the body and the mind suffer because the ability to perceive, process and reproduce information qualitatively decreases.

Therefore, healthy sleep, adherence to the daily routine, affects human health, and involves compliance with the basic rules of life, in particular, adherence to a proper daily routine, nutrition and physical activity.

The most important components of teaching a healthy lifestyle, which is based on life skills - to learn to acquire knowledge, learn to be yourself, learn to live together, learn to act (Order of the Ministry of Education and Science of Ukraine No. 998 of December 31, 2004) (On Approval of Conceptual Principles, 2004). The concept of personality-oriented competence training and education, takes into account the age and individual characteristics of students and is carried out through the use of interactive and active (training, games, etc.) technologies.

An important factor in the development of children's mental health is the presence of such qualities as love of life, cheerfulness and sense of humor in adults who surround the child (parents and teachers). The presence of this determines the optimal conditions for the development of children's psychological health. 
Table 2

Compounds and priorities of a healthy life-style in the 21 st century

\begin{tabular}{|l|l|}
\hline \multicolumn{1}{|c|}{ Compounds of a healthy life-style } & \multicolumn{1}{c|}{ Values, means, stimuli } \\
\hline $\begin{array}{l}\text { Awareness of the value of health and } \\
\text { understanding of health not only as a } \\
\text { state of absence of disease or physical } \\
\text { or other special needs of life }\end{array}$ & $\begin{array}{l}\text { The idea of the priority of the value of health in the } \\
\text { worldview of human values, the appropriate mental } \\
\text { attitude, a state of a complete well-being }\end{array}$ \\
\hline $\begin{array}{l}\text { The idea of entire understanding of } \\
\text { health as a phenomenon }\end{array}$ & $\begin{array}{l}\text { Which inextricably combines its four spheres - physi- } \\
\text { cal, mental, social, spiritual }\end{array}$ \\
\hline Absence of bad habits & $\begin{array}{l}\text { Tobacco, alcohol, drug addiction, dangerous sexual } \\
\text { intercourse }\end{array}$ \\
\hline $\begin{array}{l}\text { Access to well-balanced diet, balanced } \\
\text { nutrition }\end{array}$ & $\begin{array}{l}\text { Quality drinking water, the required amount of vita- } \\
\text { mins, trace elements, proteins, fats, carbohydrates, } \\
\text { special products and food additives }\end{array}$ \\
\hline Domestic condition & $\begin{array}{l}\text { Quality of housing, conditions for passive and active } \\
\text { recreation, level of mental and physical security }\end{array}$ \\
\hline Terms of work & $\begin{array}{l}\text { Safety not only in the physical but also in the mental } \\
\text { aspect, the availability of incentives and conditions for } \\
\text { professional development }\end{array}$ \\
\hline Movement activity & $\begin{array}{l}\text { Use of means of physical culture and sports, various } \\
\text { systems of improvement directed on increase of level } \\
\text { of physical development, its support, recovery after } \\
\text { physical and mental loads }\end{array}$ \\
\hline
\end{tabular}

Formation of a healthy life-style and health factors. The formation of a healthy lifestyle today is interpreted as a process of introducing efforts to improve health and well-being in general, in particular effective programs, services, policies that can support and improve existing levels of health (Shchurova, 2016: 334-336). A healthy life-style is a way of life of a person, the purpose of which is to form, maintain and strengthen health; associated with the level of culture of society and the individual, with the formation of needs and health-preserving social, civic competencies, motivation to maintain and strengthen health, etc. (Shevireva, 2017: 402-407).

Forming a healthy life-style and creating a healthy environment. Modern times require the creation of a healthy environment in IGSE and the formation of key competencies in students that promote health in the process of life. Therefore, the cooperation between IGSE and the family should begin with the study of the microclimate and conditions of family upbringing, the educational potential of the family, the nature, type of relationship between parents and children, joint leisure of family members, forms and methods used by parents in raising children, determining the readiness of parents to interact with the school, etc. (Pidborsky, 2016).

Both parents and teachers play an important role in maintaining and promoting the health of students and adolescents. Relevant work can be carried out in the following directions: formation of a healthy, friendly, cohesive class team with a favorable psychological climate; creating conditions for self-knowledge and self-development of each child, i.e. the development of the student's personality, creating a situation of success in extracurricular activities; organization of student self-government; education of moral values, patriotism; carrying out preventive measures with the involvement of specialists of different levels; organization of joint events with parents. 
Table 3

Factors affecting the health condition

\begin{tabular}{|l|l|}
\hline \multicolumn{1}{|c|}{ Factors } & \multicolumn{1}{c|}{ Interpretation } \\
\hline Environment & Health depends on the condition of the environment \\
\hline Genetic factor & heredity \\
\hline $\begin{array}{l}\text { Life-style and sanitary and hygienic } \\
\text { living and studying conditions }\end{array}$ & $\begin{array}{l}\text { optimal organization of the life process (according to } \\
\text { age, gender, individual characteristics and hygienic } \\
\text { norms); }\end{array}$ \\
\hline $\begin{array}{l}\text { Shifting the benchmarks from moral } \\
\text { family values to the material and social } \\
\text { situation in society; }\end{array}$ & $\begin{array}{l}\text { B. Erasov singles out the following types of values: } \\
\text { living rooms - life, health, safety, well-being, natu- } \\
\text { ral environment, social - status, position, diligence, } \\
\text { family, profession, ability to achieve; political - legal- } \\
\text { ity, civil liberty, order; moral - good, love, friendship, } \\
\text { honor, justice, mutual assistance; religious - faith, } \\
\text { God, church, salvation; aesthetic - beauty, ideal, style, } \\
\text { harmony, traditions, cultural identity, etc. }\end{array}$ \\
\hline $\begin{array}{l}\text { Lack of systematic and purposeful work } \\
\text { on prevention of unhealthy habits; }\end{array}$ & $\begin{array}{l}\text { smoking, alcohol, drugs, gambling and Internet addic- } \\
\text { tion and other deviations }\end{array}$ \\
\hline $\begin{array}{l}\text { Uncontrolled use of media and Internet } \\
\text { resources by adolescent students; }\end{array}$ & Cyberbullying, social networks, etc. \\
\hline $\begin{array}{l}\text { Limited motor activity of students } \\
\text { (hypodynamics); }\end{array}$ & $\begin{array}{l}\text { Hypodynamia - a common problem today, when peo- } \\
\text { ple do not move much, spend a lot of time in a sitting } \\
\text { or lying position, suffer from obesity }\end{array}$ \\
\hline $\begin{array}{l}\text { Increasing the amount of study load on } \\
\text { the learner }\end{array}$ & leads to fatigue, stress; \\
\hline $\begin{array}{l}\text { Imperfection of curricula and methods of } \\
\text { conservation health in IGSE }\end{array}$ & $\begin{array}{l}\text { Implementation of integrated classes "Fundamentals } \\
\text { of Health", "Physical Education" }\end{array}$ \\
\hline
\end{tabular}

It is important to carry out prevention of hypodynamia both in IGSE and at home. Motion is life. Prevention of hypodynamics should be started from childhood: children should be taught to exercise in the morning, active leisure in the fresh air, taking them to classes in sports sections. Adults should also get involved: walk outside more, play sports, if possible, go to the gym. It is important to teach children to ride a bike, swim, and so on. In shaping the health of students, teachers and parents, physicians and the public can: teach positive self-esteem and acceptance of others (adequate self-esteem); teach reflexive skills (skills of understanding their emotional reactions and the ability to express them in words; empathy); to form the need for self-development (realization of creative needs of the individual); give the child enough attention, love, care.

We agree with domestic scientists that the most important factor for creating health protecting environment is a formation of "skills of rational nutrition"; skills of movement activity and endurance; sanitary and hygienic skills; skills of organization work and leisure organization; skills of self-control; skills of success motivation and will training; skills of stress control; skills of effective communication; skills of conflict prevention; empathy skills; behavior under pressure; cooperation skills; self-awareness and self-esteem skills; definition of life goals and programs; analysis of decision-making problems of students (Obukhivska et al., 2016: 13-14).

We emphasize the importance of mental health, the focus should be on "harmony" which is within the person, and between the person and the environment. Therefore, it is important to 
maintain an active dynamic balance between the body and the environment. Researchers have shown that a person's mental health depends on a number of factors: proper nutrition, daily routine, being outdoors, physical activity, and so on. But psychological comfort is the most important.

\section{Class "Basics of Healthcare" in IGSE}

In domestic schools, the class "Basics of Healthcare" is a system-forming factor in ensuring a favorable environment for students' health. The class "Basics of Healthcare" corresponds to the main directions of education in the 21 st century. Among the key areas for the acquisition of competencies (according to UNESCO), it focuses on physical, psychological and social well-being, the development of the ability to learn as a method of learning. The teaching of the subject "Basics of Healthcare" is based on one of the most effective modern pedagogical methods - education based on the development of life and special skills, which aims to form a healthy and prosocial personality, harmoniously combines the functions of learning, education and development of socio-psychological competence student youth.

Health-protection activities of modern IGSE involve the formation of key and subject competencies in students, modernization of the educational process, creating a healthy environment and taking into account the factors influencing the state of health. It is important to create comfortable learning conditions (lesson schedule, oxygen breaks, rest rooms, media libraries, etc.). Creation of physical, physiological, mental comfort for students and cooperation on the basis of pedagogy of partnership in IGSE between parents, teachers and students. It is important to use health techniques that regulate motor activity, and methods of rehabilitation of mental and physical performance. The NUS Concept actualizes the application of multilevel and group training; sets forth the differentiation and individualization of education, and introduces inclusive education. Today, modern technologies of interactive and integrated learning are used. The teacher must ensure the cooperation with students on the "technology of success" and prevent excessive overload of students; focus their activities on the formation of a healthy lifestyle of pupils and students.

The World Health Organization argues that the organization of children's and young people's health education should be special. For health education, an approach that focuses on the individual, on the ways he or she communicates, and on the ability to find common ground with other people is appropriate - an "approach to emotional perception and skills development." The concept of "life-skills approach" in recent decades in the international scientific circulation defines the modern concept of ensuring healthy psychosocial development of children and youth, prevention of socially dangerous diseases through the formation and development of skills needed in life (World Health Organization (WHO)).

The peculiarity of lesson methodology on the fundamentals of health is based on the fact that mastering health competencies requires repeated practice. This process is most effective in the interaction of students working in groups. Therefore, it is necessary to organize practical, playful, individual and collective activities for students, based on the subject-subject interaction of the teacher with students and among students. The structure of lessons on the fundamental of health should be flexible, organically combining educational-cognitive and health-motor activities of students, including different types of dialogue and group cooperation. Emotionality and accessibility of educational material and its visualization are of great importance for the formation of a healthy lifestyle and safe behavior in students. 
Modern IGSE use new information technologies in the educational process, students primarily use the computer as a source of information, a means of learning. This work with gadgets, computers involves constant nervous tension, unbalanced diet, lack of culture of using IT technologies, low health in the hierarchy of values of students and youth. There is a need to address issues related to the health of young people, the formation of teachers' responsible attitude to their own health, and the competence to use technologies to preserve the health of students during lessons in primary school. Health-preserving competence means characteristics, properties, aimed at maintaining physical, social, spiritual and mental health of oneself and one's environment. Components of this competence are life skills that promote a healthy lifestyle. The essence of a person's health competence is the ability to apply the skills of a healthy lifestyle and safety of life; to use skills of personal hygiene, prevention of diseases and injuries, safety rules (Savchenko, 2009: 112).

The main tasks of the promotion of a healthy lifestyle and sports among students are the involvement of students and pupils of IGSE in physical culture and sports; increasing students' interest in physical education lessons, basics of health; learning a healthy lifestyle; prevention of offenses and bad habits; involvement of parents, doctors, the public in the organization of health activities.

\section{Conclusions}

The concept of "health" is interpreted in the modern world not only as the absence of diseases, but also includes certain ways of thinking and behaving that increase the level of general well-being, ensure self-realization and success in life. That is, a healthy lifestyle covers various areas of human life and is implemented through behavior, specific actions, and deeds. It is important to prevent bad habits and diseases, learn to follow the rules of hygiene, etc.

Health-preserving environment is the priority of the health-improving direction of the educational process in IGSE in conditions of NUS, teaching a healthy lifestyle. A healthy lifestyle is a holistic way of life for people, aimed at the harmonious unity of all functions, based on many factors of human life: family, work, leisure. Further lifestyle, promoting the development of personal potential, depends significantly on the success to form and instill conscious skills of a healthy way of life in IGSE.

Therefore, today, care for the health of students, maintaining and improving health within the implementation of NUS Concept is a mandatory objective of each IGSE in the process of cooperation on the basis of pedagogy partnership of teachers, parents, students, doctors, members of the public. "Fundamentals of Health," is a subject in IGSE, which develops life skills favorable to the health, safety, successful socialization and self-realization of students. The condition for the effectiveness of this work is the professionalism of teachers, taking into account various factors of a healthy lifestyle, in particular to teach students to use the abilities of their body, to master the life skills of healthy behavior. It is important to form the values and beliefs of all participants in the educational process, which contribute to the conscious choice of a healthy behavior. The educational process should be aimed at developing health-preserving competencies, training students and pupils to perform practical actions that prevent the formation of diseases and strengthen the whole body, teach hygiene, proper nutrition, necessary physical activity, motor skills; formation of universal values in schoolchildren, formation of the need for a healthy lifestyle. It is important to develop physical abilities in children, encourage them to be physically active on a regular basis, make them ready to defend their Motherland, etc. 
The study does not cover all aspects of the problem under research. In the future, it is necessary to pay attention to determining the condition of health among students and pupils, to study the use of modern pedagogical interactive technologies for the formation of healthy competencies in students, to prepare individual development programs for the formation of health values of students with special educational needs.

\section{References}

Bojchuk, Yu. D. (2018). Suchasni pidxody do rozuminnya sutnosti zdorov'ya lyudy 'ny ta sumizhny'x $z$ ny 'm ponyat ' [Modern approaches to understanding the essence of human health and related concepts]. http://hnpu.edu.ua/sites/default/files/files/Kaf_zdor_ta_korr_os/Zagalna_ teorija_zdorovia_i_zdorviazberegennja.pdf [in Ukrainian]

Vsesvitnya organizaciya oxorony z zorov'ya (VOOZ) [World Health Organization (WHO)]. https://www.who.int [in English]

Erasov, B. S. (2000). Social Cultural Studies: a textbook for students of higher educational institutions. Prod. third, supplement and processing. M.: Aspect Press, 591 s. [in Russian]

Skry pchenko, O. V. (2005). Zagal'na psy xologiya. pidruch. dlya stud. [General Psychology. Textbook for students]. VNZ / za red. - K.: Ly`bid', 454 c. [in Ukrainian]

Zdorov'ya lyudy`ny' na 50\% zalezhy 't vid sposobu zhy 'ttya - VOOZ [50\% of human health depends on lifestyle]. https://www.unn.com.ua/uk/news/563480-zdorovya-lyudini-na-50proczalegeit-vid-sposobu-geittya-vooz [in Ukrainian]

Kornacz 'ky j, V. M. Problemy`zdorov'ya ta podovzhennya try valosti zhy 'ttya naselennya Ukrayiny' [Health problems of prolonging the life expectancy of the population of Ukraine]. https://www.umj.com.ua/article/2596/problemi-zdorov-ya-ta-podovzhennya-trivalosti-zhittya-naselennya-ukraini [in Ukrainian]

Pidbors 'ky j, Yu. G. (2016). Problemy`formuvannya zdorovogo sposobu zhy ‘tya v suchasnij zagal noosvitnij shkoli [Problems of healthy lifestyle in a modern comprehensive school]. http://molodyvcheny.in.ua/files/journal/2016/9/34.pdf [in Ukrainian]

Pro zatverdzhennya Konceptual `ny ‘ zasad rozvy 'tku pedagogichnoyi osvity 'v Ukrayini ta yiyi integraciyi v yevropejs 'ky josvitnij prostir (2004) [About the statement of conceptual bases of development of pedagogical education in Ukraine and its integration into the European educational space]. http://ru.osvita.ua/legislation/Vishya_osvita/3145/[in Ukrainian]

Savchenko, O. Ya. (2009). Vy xovny j potencial pochatkovoyi osvity ‘ posibny $k$ dlya vchy teliv ta metody stiv pochatkovogo navchannya [Educational potential of primary education: a guide for teachers and methodologists of primary education]. Savchenko., O. Ya., -2- ge vy'd., dopovn., pererobl. - K.: Bogdanova, A. M. 226 s. [in Ukrainian]

Obuxivs 'ka, A. G., Zhuk, T. V., Zelen 'ko, O. A. ta in (2016). Suchasni texnologiyi zberezhennya zdorov'ya uchniv u diyal 'nosti psy ’xologichnoyi sluzhby' i psy ‘xologo-medy 'ko-pedagogichny x konsul tacij / za red. Obuxivs koyi, [Modern technologies for maintaining the health of students in the activities of psychological services and psychological, medical and pedagogical consultations ledited by Obukhivska]. A. G. - K.: UNMCz prakty 'chnoyi psy 'xologiyi i social'noyi roboty', 2016. S. 13-14. [in Ukrainian]

Shevy r'ova, G. G. (2017). Formuvannya zdorovogo sposobu zhy 'ttya shkolyariv yak aktual 'ne zavdannya profesijnoyi diyal 'nosti vchy 'telya // Vzayemodiya duxovnogo j fizy chnogo vy ‘xovannya $v$ stanovlenni garmonijno rozvy`nenoyi osoby stosti: zbirny $k$ statej za materialamy' IV Mizhn. Naukovo-prakty chnoyi onlajn-konferenciyi [Formation of a healthy lifestyle of schoolchildren is an urgent task of professional activity of a teacher // Interaction of spiritual 
and physical education in the formation of a harmoniously developed personality: a collection of articles based on the materials of the IV international scientific-practical online conference]. (Slov'yans `k, Ukrayina, 23-24 bereznya 2017) u 2 tomax / gol. red. V. M. Pry ‘sty 'ns 'ky j. Slov'yans 'k: DVNZ “Donbas `ky j derzhavny j pedagogichny j universy 'tet”, 2017. S. 402-407. [in Ukrainian]

Shhurova, N. V. (2016). Rol zdorov'ya zberezhuval 'nogo seredovy 'shha zagal'noosvitn 'ogo navchal 'nogo zakladu v zmicznenni zdorov'ya shkolyariv // Naukovy j visny $k$ Uzhgorods 'kogo nacional nogo universy tetu: Seriya: Pedagogika. [The role of health of the preserving environment of a secondary school in strengthening the health of schoolchildren // Scientific Bulletin of Uzhgorod National University: Series: Pedagogy]. Social na robota / gol. red. I. V. Kozubovs 'ka. - Uzhgorod: Vy`davny cztvo UzhNU “Goverla”, 2016. Vy'p. 1 (38). S. 334-336. [in Ukrainian] 